\title{
UPAYA MENINGKATKAN MOTIVASI BELAJAR SENI BUDAYA MELALUI MEDIA PAMERAN KARYA SENI KELAS VIII SMP NEGERI 6 TEBING TINGGI
}

\author{
Roima \\ Surel: rroima31@gmail.com
}

\begin{abstract}
ABSTRAK
Tujuan penelitian ini adalah untuk meningkatkan prestasi Belajar Seni Budaya dan Ketrampilan. Pada peserta didik Kelas VIII SMP Negeri 6 Tebing Tinggi dengan menggunakan media Pameran. Bentuk penelitian ini adalah penelitian tindakan kelas dengan menggunakan model siklus. Tiap siklus terdiri dari empat tahap, yaitu perencanaan, pelaksanaan, observasi dan refleksi. Adapun jumlah peserta didik Kelas VIII SMP Negeri 6 Tebing Tinggi adalah 32. Berdasarkan hasil penelitian dapat disimpulkan bahwa, ada peningkatan prestasi belajar Seni Budaya dan Ketrampilan, setelah diadakan tindakan kelas dengan media pameran. Hal ini dapat ditunjukan dengan meningkatkan motivasi siswa dari sebelum dan sesudah tindakan. Pada silkus I ada peningkatan nilai dari rata rata 62,75 meningkat menjadi 74,57 pada siklus II meningkat menjadi demikian dapat disimpulkan bahwa pembelajaran SBK dengan menggunakan media pameran dapt meningkatkan prestasi belajar SBK pada peserta didik Kelas VIII SMP Negeri 6 Tebing Tinggi.
\end{abstract}

Kata kunci: Motivasi Belajar, Media Pameran Karya Seni

\section{PENDAHULUAN}

Dikalangan masyarakat akhirakhir ini berkembang polemik tentang merosotnya mutu pendidikan di Indonesia. Salah satu penyebab merosotnya mutu pendidikan di Indonesia adanya ketidakseimbangan mata pelajaran yang diberikan guru kepada siswa. Ada mata pelajaran yang diprioritaskan dan ada mata pelajaran yang dikesampingkan. Selama ini pelajaran bidang akademik lebih diutamakan daripada pelajaran non akademis khususnya pelajaran kesenian dan ketrampilan. Padahal pelajaran bidang akadmik yang dijadikan sebagai tolak ukur keberhasilan pendidikan di Indonesia, sebenarnya hanya mengembangkan otak kiri saja yang memiliki fungsi antara lain: sequen (mengikuti aturan), analysis (kemampuan menganalisa), linear (terarah atau lurus), computarion (penuh perhitungan), logic (logika), fact (segala sesuatunyata), sedangkan otak kanan berfungsi holistik (menyeluruh), intuition (paham tanpa pikir), creatif (penuh kreatifitas), day dreaming (mengembangkan anganangan), imagination (imajinasi), dan feeling (perasaan) selama ini hampir tidak mendapat kesempatan berkembang, karena pelajaran kesenian dan ketrampilan yang dapat mengembangkan fungsi otak kanan diabaikan (Drs. Slamet Rahardjo: 2002, Metodologi Pengembangan Kompetensi Mengajar Kesenian Guru Kelas Sekolah Menengah Pertama. Salatiga; Diklat Guru KTK). Pengembangan fungsi otak 
kiri dan kanan yang tidak seimbang menjadikan siswa bodoh, tidak kreatif, tidak berkembang feeling, dan imajinasinya. Pelajaran yang bersifat memupuk kreatifitas siswa dan penuh kegembiaraan sesuai dengan anak - anak tidak mereka dapatkan, sehingga siswa menadi jenuh, bosan dan tidak bergairah mengikuti pelajaran. Kegiatan di sekolah hanyalah rutinitas yang dipaksakan. Belajar bukan lagi suatu kebutuhan, melainkan suatu beban yang sangat tidak menyenagkan bagi siswa. Mereka datang kesekolah tanpa kerinduan dan gairah dalam belajar, karena keatifitas yang sesuai dengan dunia anak - anak hampir tak pernah mereka temukan. Perkembangan antara otak kiri dan kanan berjalan tidak seimbang. Hal inilah yang menjadi salah satu penyebab merosotnya mutu pendidikan di Indonesia.

Untuk meningkatkan gairah belajar siswa khususnya, serta untuk meningkatkan mutu pendidikan pada umumnya, maka mata pelajaran KTK khususnya Seni Budaya harus diberi tempat yang sederajat. Dengan mata pelajaran lain, karena Seni Budaya dapat difungsikan sebagai media ekspresi, media komunikasi, media bermain, media pengembangan bakat, dan media Pendidikan Kesenian oleh Dra Ida Siti Herawati, Drs Iriaji. Disamping berfungsi sebagai media, Seni Budaya juga dapat dipakai sebagai sarana untuk menyampikan pesanpesan moral, etika, budi pekerti, estitika dan pasan-pesan pendidikan lainnya yang dengan mudah dapat diterima oleh pemirsa karena Seni Budaya merupakan alat komunikasi yang universal. Menurut Rasjoyo (Cahyono, 1994) pameran meningkatkan motivasi belajar.hal ini juga sejalan dengan yang di kemukaan oleh Wartono (1984:69) hubungan antara pameran dengan motivasi belajar Seni Budaya sangat erat hal tersebut sesuai dengan pembelajaran Seni Budaya yang model pembelajaran terpadu.

Dalam program semester II kelas VIII terdapat pokok bahasan pameran atau pergelaran.Pokok bahasan ini hampir tidak disentuh Guru Sekolah Menengah Pertama. Selama hampir 20 tahun peneliti bertugas sebagai guru Sekolah Menengah Pertama, belum pernah melihat guru menyelenggarakan pameran atau pergelaran seni. Mengapa hal ini terjadi? Pelajaran Seni Budaya dianggap tidak penting. motivasi belajar Seni Budaya?

Berdasarkan hasil pengamatan dan analisis data yang ada dapat dilihat adanya peningkatan aktivitas peserta didik dalam pembelajaran, serta perkembangan prestasi belajar Seni Budaya dan Ketrampilan Kelas VIII SMP Negeri 6 Kota Tebing Tinggi. Peningkatan tersebut antara lain :

a. Peserta didik lebih aktif memperhatikan penjelasan guru.

b. Peserta didik lebih aktif melakukan kegiatan yang diberikan guru 
c. Keberanian menampilkan karya seni meningkat.

d. Kerja sama dengan teman lebih meningkat.

e. Ketrampilan menyusun karya seni meningkat Peserta didik lebih aktif mengerjakan tugas dari guru

Tujuan yang ingin dicapai dalam penelitian ini adalah "Untuk meningkatkan prestasi belajar Seni Budaya melalui pameran Seni Budaya Kelas VIII SMP Negeri 6 Kota Tebing Tinggi”,

\section{METODE PENELITIAN}

Penelitian dilaksanakan di Kelas VIII SMP Negeri 6 Kota Tebing Tinggi Propinsi Sumatera Utara, dengan alasan:

a. SMP Negeri 6 Tebing Tinggi pernah menjadi tempat penelitian.

b. SMP Negeri 6 Kota Tebing Tinggi nilai rata-rata SBK rendah dibandingkan dengan mata pelajaran yang lain.

c. Peneliti berada di kecamatan tersebut.

Subjek penelitian ini adalah Kelas VIII SMP Negeri 6 Kota Tebing Tinggi, yang berjumlah 32 peserta didik.

\section{Teknik Pengumpulan Data}

Sesuai dengan bentuk sumber data yang dimanfaatkan dalam Penelitian Tindakan Kelas, maka teknik pengumpulan data yang digunakan dalam penelitian ini adalah:
Wawancara digunakan untuk mengelahui tanggapan siswa dan guru terhadap proses pembelajaran dengan media pameran. Dalam penelitian ini, observasi digunakan untuk mengetahui keaktifan siswa dan kinerja guru selama proses pembelajaran. Instrumen yang digunakan adalah lembar observasi. Tes tertulis digunakan untuk memperoleh data hasil belajar siswa.

Dalam penelitian tindakan kelas ini, teknik analisis data yang digunakan adalah teknik deskriptif. datayang dianalisis berupa rata-rata dan prosentase hasil belajar siswa. Data yang diperoleh disajikan dalam bentuk label dan diagram.

Untuk mengetahui keberhasiJan Penelitian Tindakan Kelas ini, penulis menetapkan indikator mkinerja:

a. Rata-rata nilai tes hasil belajar siswa tentang sifat-sifat kesebangunan dan simetri di atas nilai KKM, yaitu 70 .

b. Siswa yang mendapat nilai di atas KKM minimal sebanyak $70 \%$.

Prosedur atau langkahlangkahpenelitian Tindakan Kelas ini terdiri dari siklus-siklus. Observasi yang dilakukan oleh peneliti adalah observasi langsung dan partissipataif agar hasilya subjektif mungkin. Observasi langsung (direct observation), yaitu observasi yang dilakukan tanpa perantara (secara langsung) terhadap objek yang diteliti.Sedangkan observasi partisipatif yaitu 
pengamatan yang dilakukan dengan cara ikut ambil bagian atau melibatkan diri dalam situasi objek yang diteliti. (H. Muhammad Ali, 1993:72). Observasi dilakukan pada peserta didik Kelas VIII SMP Negeri 6 Kota Tebing Tinggi untuk mengetahui minat dan perhatianya selama proses pembelajarn berlangsung Mengadakan refeleksi dan evaluasi dari kegiatan 1, 2, dan 3 berdasarkan hasil refleksi ini akan dapat diketahui kelemahan kegiatan pembelajaran yang dilakukan oleh guru, sehingga dapat digunakan untuk tindakan kelas pada siklus berikutnya. Bila refleksi dan evaluasi siklus I menunjukan adanya peningkatan prestasi maupun motivasi pada peserta didik Kelas VIII SMP Negeri 6 Kota Tebing Tinggi, maka dibuat siklus II yang meliputi tahap perencanaan tindakan, tahap pelaksanaan tindakan, tahap observasi tindakan, tahap refleksi. Sehingga peserta didik benar-benar mampu meningkatkan prestasi belajar Seni Budaya dan Ketrampilan.

\section{HASIL PENELITIAN DAN PEMBAHASAN}

Peserta didik kelas VIII SMP Negeri 6 Kota Tebing Tinggi berjumlah 32 anak, yang terdiri dari 8 laki-laki dan 24 perempuan. Prestasi mereka rata-rata tidak ada yang begitu menonjol. Dari jumlah 32 anak tersebut kebanyakan prestasi / nilainya banyak yang di bawah 70 . Khususnya mata pelajaran Seni Budaya dan Ketrampilan (SBK).
Oleh sebab itu saya sebagai guru kelas harus dapat mengatasi hal tersebut,agar supaya semua peserta didik dapat mencapai nilai standar 70. Kondisi yang demikian ini menarik bagi saya untuk mengadakan kegiatan tindakan kelas, untuk menemukan masalah-masalah dalam proses pembelajaran SBK. Jika permasalahan yang berkaitan dengan pembelajaran SBK dapat dipecahkan melalui media pameran, maka diharapkan prestasi peserta didik akan meningkat. Proses Pembelajaran selama ini masih tradisional,belum menggunakan pembelajaran yang inovatif. Penggunaan media,alat peraga metode dan model pembelajaran masih kurang efektif. Pada umumnya pembelajaran masih menggunakan metode ceramah dan berpusat pada guru Khususnya mata pelajaran SBK dan Kompetensi dasar pameran belum pernah diberikan senhingga hasilnya masih rendah.

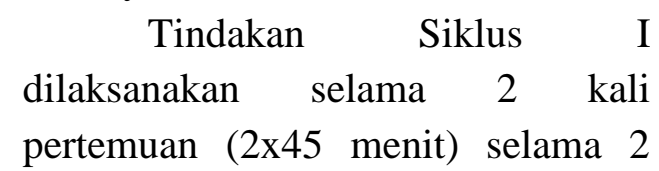
minggu dalam bulan Pebruari 2017. Pada silkus I dilaksanakan dilaksanakan dalam 2 pertemuan (dengan alokasi waktu 2x 35 menit) yaitu pada tanggal 1 Februari 2017 dan 1 Maret 2017. Dengan berpedoman pada kurikulum tingkat satuan pendidikan SMP Kelas VIII.

Dalam hal ini guru menerapkan pembelajaran melalui media Pameran yang dengan rencana pembelajaran yang telah disusun. Pembelajaran yang telah 
disusun pada siklus I ini akan dilaksanakan dua kali pertemuan. Pertemuan pertama dengan kegiatan:

a. Orientasi (5 menit)

Sebelum pembelajaran guru mengenalkan terlebih dahulu hasil hasil lomba lukis anakanak.

b. Ekplorasi (20 menit)

Guru mengajak peseta didik melihat hasil karya Seni Budaya yang dipamerkan guru .Guru memjelaskan cara membuatnya.

c. Interprestasi (15 menit)

Guru meminta peserta didik untuk menggambar apa yang mereka lihat dengan bantuan guru.

d. Guru mengajak peserta didik untuk melihat hasil karya sendiri dan membandingkan dengan hasil karya temanya.

Pertemuan kedua

a. Orientasi (5 menit)

Guru mengulas kembali materi pelajaran yang lalu.

b. Ekplorasi (20 menit)

Guru mengajak peserta didik berdiskusi menentukan Tema dari pameran yang akan dilaksanakan. Dan menyiapkan karya seni yang telah dibuat.

c. Interpetasi (15 menit)

Guru meninta hasil karya peserta didik dan membuat panitia pameran serta menyeleksi hasil karya yang layak dipamerkan.

d. Rekresi (20 menit)

Guru mengajak siswa mengataur hasil karya seni yang akan dipamerkan didalam kelas.
Kegiatan observasi dilakukan bersamaan dengan pelaksanaan tindakan Yaitu pada proses pembelajaran SBK dengan $\mathrm{KD}$ mengekpresikan diri melalui karya seni, dan materi pameran. Kegiatan yang dilakukan peneliti :

a. Peneliti memonitor peserta didik selama proses pembelajaran.

b. Peneliti menilai hasil yang dicapai setelah pembelajaran.

Dari hasil penelitian pada siklus I , maka peneliti mengulas masih ada 11 Peserta didik belum tuntas yang masih sama dan 3 peserta didik dibawah KKM. Maka peneliti melanjutkan siklus ke II dengan menindak lanjuti siklus I.

Kendala dan Masalah yang muncul dalam pelaksanaan Pembelajaran siklus I Dalam pelaksanaan pembelajran silkus I banyak kendala serta masalah yang kami temukan kendala:

a. Guru belum melaksanakan alokasi KBM dengan baik

b. Guru belum optimal memantau kegiatan peserta didik

c. Guru kuang tegas dalam menegur peserta didik yang kurang memperhatikan

d. Guru kurang menguasai teknik melukis dengan baik.

e. Guru kurang memehami karakteristik seni anak SD

f. Guru kurang memotivasi untuk berkreatifitas dalm bidang seni. 
Masalah :

a. Anak kurang memperhatikan pembelajaran

b. Anak kurang percaya diri menampilkan karya seni. Anak tidak mau mengoleksi hasil karya seninya.

c. Anak tidak mendapatkan kepuasan atas hasil karyanya sendiri. Anak enggan belajar Seni Budaya dan Ketrampilan

d. Anak tidak berminat mengikuti pameran kelas.

Strategi yang saya pakai dalam menyelesaikan masalah yaitu dengan memanfaatkan pengetahuan peserta didik delam pembelajaran SBK. Dengan lingkungan sekitar anak akan lebih termotivasi dan minat belajar anak meningkat dengan demikian berbagai masalah yang muncul akan teratasi muaranya tujuan tercapai sesuai yang saya harapkan.

a. Anak diajak keluar kelas menikmati indahnya kebun sekolah

b. Anak mengingat pengalaman masing-masing.

c. Anak bersama guru mendiskusikan tema yang akan dipilih.

d. Anak melukis sesuai dengan apa yang mereka ingat.

e. Anak memaparkan/diceritakan hasil lukisanya.

f. Anak menanggapi hasil karya temannya.

g. Anak bersama guru menyimpulkan hasil tugas yang dibuat anak
Tindakan silkus

II

dilaksanakan tanggal 6 April dan 28 April 2017. Perencanaan kegiatan dilaksanakan 2 kali pertemuan. Penelitian ini dilakukan dengan menggunakan metode penelitian tindakan kelas yang terdiri dari siklus-siklus.

Berdasarkan hasil refleksi dan evaluasi pelaksanaan tindakan pada siklus I diketahui bahwa pembelajaran Seni Budaya dan Ketrampilan yang dilaksanakan pada siklus I belum menunjukan adanya peningkatan kemampuan belajar SBK melalui penggunaan media pameran. Oleh karena itu peneliti menyusun rencana pelaksanaan pembelajaran kembali dengan menggunakan media Pameran dan indikator yang berbeda. Adapun indikator yang dibuat sebagai dasar penyusunan rencana pelaksanaan pembelajaran kembali pada siklus II adalah sebagai berikut :

a. Membuat denah pameran.

b. Menyiapkan semua karya Seni Budaya yang telah dibuat.

c. Menata karya Seni Budaya untuk pameran kelas.

d. Menata karya Seni Budaya sesuai dengan jenisnya.

Sebagai tindak lanjut untuk lebih meningkatkan hasil belajar peserta didik melalui media Pameran untuk meningkatkan dan mempertahankan pencapaian penguasaan materi yang ditunjukan untuk mempertahankan dan memperluas pengetahuan peserta didik tentang prestasi belajar SBK. 
Pada siklus I,maka peneliti perlu menambah pada siklus berikutnya.

Dalam tahap ini guru menerapkan pembelajaran melalui media Pameran sesuai dengan rencana pelaksanaan pembelajarn yang telah disusun. Pembelajaran yang telah disusun pada siklus I ini akan dilaksanakan 2 (dua) kali pertemuan. Pertemuan pertama dengan kegiatan:

a. Orientasi (5 menit)

Sebelum pembelajaran guru mengenalkan terlebih dahulu mengenai materi yang akan dibahas yaitu penggunaan media Pameran.

b. Eksporasi (20 menit)

Guru mengajak peserta didik berdiskusi tentang urut-urutan penyelenggaraan Pameran. Guru meminta peserta didik membuat Contoh Gambar pameran dengan pengalamanya masing-masing.

c. Interpetasi

Guru meminta peserta didik untuk memperlihatkan hasil karya Seni Budaya gambar Guru membantu memberi pengarahan dan teknik melukis dengan benar.

d. Rekreasi (20 menit)

Guru mengajak keluar peserta didik untuk menata hasil karya yang telah dibuat.

Pertemuan kedua dengan kegiatan:

a. Orientasi (5 menit)

Guru mengulas kembali materi pelajaran yang lalu. b. Guru mengajak peserta didik berdiskusi tentang urutan dan tata cara mengadakan pameran.

c. Guru meminta peserta didik menata hasil karya untuk dipamerkan.

d. Interprestasi (15 menit)

Guru meminta peserta didik untuk menyeleksi karya seni yang akan dipamerkan. Guru membantu menyeleksi.

e. Rekreasi (20 menit)

Guru mengajak peserta didik menata tempat pameran sekolah

Kegiatan obesrvasi dilakukan bersamaan dengan pelaksanaan tindakan yaitu pada proses pembelajaran SBK dengan KD Menata karya Seni Budaya yang diciptakan dalam bentuk pameran sekolah.

a. Guru bersama anak penata hasil karya Seni Budaya yang dibuatnya.

b. Guru menilai hasil karya yang di pamerkan.

Setelah pelaksanaan siklus II selesai dilakukan,maka dapat diketahui kemampuan peserta didik dalam menyelesaikan tugas dengan melihat hasilnya dimana nilai hasil tes meningkat dan telah mencapai 100 ketuntasan. Dari hasail penelitian pada siklus II ini,maka peneliti tidak perlu dilanjutkan pada siklus berikutnya. Namun guru harus terus melaksanakan bimbingan belajar untuk mempertahankan pada hasil belajar dan parsisipasi serta 
suasana dalam kelas sebagai tindak lanjut.

Pada pelaksana siklus II ini tidak ada kendala atau pun masalah yang sangat berarti hanya saja masih ada beberapa peserta didik yang kurang aktif tentang materi yang diajarkan serta masih terbatasnya kemampuan mereka mengeluarkan ekpresi diri melalui lukisan. Rancangan Strategi penyelesaian masalahnya adalah: Memberi motivasi dan arahan kepada peserta didik agar tidak malu menmpilkan hasil karyanya apabila belum mampu menampilkan karyanya.

\section{Pembahasan}

Dari hasil tes kondisi awal rata-rata nilai peserta didik adalah 62,75 setelah dilaksanakan siklus I nilai rata -rata peserta didik meningkat menjadi 74,54 bahwa terjadi peningkatan hasil pada siklus II semua peserta didik mencapai nilai tuntas diatas $\mathrm{KKm}$ membuktikan dangan media pameran mampu meningkatkan motivasi dan prestasi belajar Seni Budaya dan Ketrampilan Kelas VIII SMP Negeri 6 Kota Tebing Tinggi tahun pelajaran 2016/2017.

\section{SIMPULAN}

Berdasarkan hasil penelitian tindakan kelas yang telah dilaksanakan dua siklus dengan media pameran dalam pembelajaran SBK pada peserta didik Kelas VIII SMP Negeri 6 Kota Tebing Tinggi Tahun Pelajaran 2016/2017 dapat disimpulkan sebagai berikut : a. Pembelajaran dengan menggunakan media pameran efektif untuk meningkatkan motivasi, prestasi belajar SBK SD Negeri Wunut, dapat dilihat pada daftar nilai siklus II terlampir.

b. Cara meningkatkan motivasi, prestasi belajar dengan menggunakan media pameran adalah: Media Pameran dibuat yang menarik, Guru harus trampil memilih tema serta menyusun hasil karya peserta didik, Peserta didik harus menyukai dan mau melaksanakanya.

c. Cara mengatasi kendala yang dihadapi guru dalam menggunakan media pameran adalah: Karena jumlah peserta didik cukup banyak yang ingin mengikuti maka guru mengadakan seleksi karya seni sesuai dengan jenisnya. Berdasarkan hasil penelitian tindakan kelas dengan menggunakan dua siklus tersebut diatas, ternyata hipotesus yang dirumuskan telah terbukti kebenaranya. Ternyata pembelajaran menggunkan media pameran dapat meningkatkan motivasi, prestasi pembelajran SBK SMP Negeri 6 Kota Tebing Tinggi tahun Pelajaran 2016/2017. Dengan demikian penerapan pembelajaran SBK dengan menggunakan media pameran dapat dilaksanakan untuk meningkatkan mutu 
pembelajaran SBK khususnya Seni Budaya Kelas VIII sehingga dapat meningkatkan motivasi,prestasi belajar peserta didik.

Dalam akhir pembahasan ini akan disampaikan saran-saran yang mungkin membawa manfaat yang besar dalam usaha kita meningkatkan mutu pendidikan.

\section{DAFTAR RUJUKAN}

Depdikbud Direktorat jendral pendidikan tinggi proyek pembinaan tenaga Direktorat pendidikan Dasar dan Menengah.

Raharjo, Slamet. 2002. Metedologi Pengembangan Kompetensi Mengajar Kesenian Guru Kelas Sekolah Menengah Pertama, Salatiga.

Retno, Winarni. 2016. Penelitian Tindakan Kelas Salatiga.

Slamet, Suwarto. 2007. Dasar-dasar Metodologi Penelitian

Kualitatif. Surakarta: UNS Press.

Zakarias Azis, dkk. 2016. Pendidikan Seni Direktorat Jendral Pendidikan Tinggi Kementrian Pendidikan Nasional. 